\title{
“Don't You Reckon That Being a Multilingual Person Is Cool?"-Investigating the L3 Learning Motivation of Chinese University Learners
}

\author{
Xinyue Zhang \\ HKU SPACE Community College, Hong Kong University, Hong Kong, China \\ Email: valentinaxinyue@163.com
}

How to cite this paper: Zhang, X. Y. (2020). "Don't You Reckon That Being a Multilingual Person Is Cool?"-Investigating the L3 Learning Motivation of Chinese University Learners. Open Journal of Social Sciences, 8, 453-461. https://doi.org/10.4236/jss.2020.88038

Received: July 29, 2020

Accepted: August 28, 2020

Published: August 31, 2020

\begin{abstract}
In order to deepen our understanding of relationship between third language learning motivation and third language acquisition (TLA), this paper reports on a case study on L3 motivation of two Chinese university students with very similar profiles studying Italian and Thai as L3 respectively. Through analyzing interview transcripts, this study centers on the nuanced picture of differences in learning behavior of two language learners, making an explicit enunciation of their motivational type, following the framework of L2 Motivation Self System (L2MSS) proposed by Dörnyei (2009) and the Self-discrepancy model for language learners (Lanvers, 2016).
\end{abstract}

\section{Keywords}

Motivation, L3 Motivation, L2MSS, Self-Discrepancy Model, Individual Differences

\section{Introduction}

The fact of English being a lingua franca (ELF) has relatively obscured the study of languages other than English (LOTEs) (Dörnyei \& Al-Hoorie, 2017). As corroborated by Boo, Dörnyei and Ryan's research (2015), under Dörnyei (2009)'s L2 Motivation Self System (L2MSS), the augmentation of studies regarding motivation of learning English as a second language (ESL) was conspicuous. And Boo's team suggested that more research on motivation to learn LOTEs is needed to fill the gap in theoretical principles which have been overshadowed by Global English. Based on L2MSS and Self-discrepancy theory (Higgins, 1987), Lanvers (2016) proposed the Self-discrepancy Model for Language learners which bisects the ideal self into Own/Other-Ideal and the Ought-to Self into Own/Other-Ought, differentiating effects exerted by Own and Other. As multilingualism has become a 
prevalent phenomenon, more studies have been conducted on learning motivations of a third language (Henry, 2011; Róg, 2017). This study can fill the gap in the literature by providing an in-depth illustration of L3 learning motivation of young Chinese learners of LOTEs.

\section{Literature Review}

\subsection{L2 Motivation Self System}

In recent years there has been considerable interest in L2MSS (Dörnyei \& Ushioda, 2011). A growing body of literature concerning L2 motivation is under the theoretical framework of L2MSS (Islam, Lamb, \& Chambers, 2013; Subekti, 2018). Since the L2MSS supplies a theoretical foundation to dynamically re-theorize language motivation (Wang \& Liu, 2017), it is adopted to investigate L3 motivation in this study.

L2MSS encompasses three main concepts: Ideal L2 Self, Ought-to L2 self and L2 Learning Experience. The concept of Ideal L2 Self refers to an imaginary future image of being adept at the specific L2. Dörnyei (2009) defines Ought-to L2 Self as: a reflection of "the situation where learners feel pressured to learn a L2 in order to avoid the negative consequences of not learning it" (p. 29). L2 Learning Experience concerns with external factors and previous learning process which affect L2 learners' learning motives, e.g., peer pressure and former achievements in languages learning (Dörnyei, 2009).

\subsection{Self-Discrepancy Model for Language Learners}

In the realm of psychology, Higgins (1987) underlines that people may have different self-guides when specifying their goals. Strong desires and duties refer to Ideal Self-guides and Ought Self-guides respectively. If people find that their real self is incompatible with their Self-guide, then they will suffer from such self-discrepancy. She proposed two standpoints on the Self except for the Ideal and Ought-to Self: the Own standpoint and the Other standpoint. As a result, there are totally 4 possible selves.

The Own-Ideal Self represents the learner's inner desire to obtain knowledge. for instance, students imagine themselves being confident when using L2. The Own-Ought Self describes the learner's intrinsic belief that it is his/her responsibility to attain certain level of L2. In this respect, Asian students may work hard to fulfill their obligation of filial piety. The Other-Ideal Self refers to other people's vision of what the learner should be, representing their hopes and wishes. For example, teachers may expect their students to be fluent when speaking in L2. The Other-Ought Self indicates the extrinsic obligations imposed on the learner and thus it is his/her duty to fulfill. For instance, students are required to pass national exams to pursue higher education.

\subsection{Empirical Studies on LOTEs Motivation}

Research on learning LOTEs is gradually rising (Gearing \& Roger, 2018; Huang, 
2019) in order to better understand LOTEs which has been clouded by English. In a longitudinal study which centers on L3 students' motivational dynamics, Wang and Liu (2017) investigated the connection between the Ideal/Ought-to L3 Selves and the L3 Learning Experience. By conducting semi-structured interviews on five freshmen whose L3 is German in a Chinese university. They found dynamic fluctuation in participants' L3 motivation during the examined educational period under the framework of L2MSS. While learners' Ought-to L3 selves showed a downward trend, the Ideal L3 selves went through a salient rising before a general decline.

Although scholars intend to fill in the gap between English and LOTEs, L2 and L3, there is still a paucity of studies with emphasis on motivation of LOTEs as a L3, especially in a Chinese context. To fill in this gap of knowledge, two research questions are put forward:

1) How do the two target Chinese university freshers' Ideal and Ought-to L2 Selves motivate their L3 learning?

2) Predicated by L2 Motivation Self System, how do learners' Learning Experiences influence their L3 motivation?

\section{Methodology}

\subsection{Research Setting and Participants}

The two Chinese learners chosen for this study were from the same local high school in Shenzhen, one of the Special Economic Zones in China. To maintain confidentiality, all the real names were replaced by pseudonyms.

These participants were chosen through convenience sampling for this case study. The details of all the participants are shown in Table 1.

\subsection{Instruments: Interviews}

A questionnaire which adheres to the L2MSS framework was designed first to collect basic quantitative data on participants' L3 motivation to assist further qualitative investigation. Different sets of semi-structured interview questions were created based on participants' responses to cover quantitative shortage and glean qualitative data. The interviews lasted 45 to 55 minutes and were recorded with participants' consent in case of the need for further inquires to clarify the uncertainties. Moreover, participants were ensured that their private data is protected and used only for academic purpose to reduce the expectation bias.

Table 1. Participants profile.

\begin{tabular}{ccccccc}
\hline Pseudonym & L3 & Age & $\begin{array}{c}\text { Gender } \\
(\mathrm{M} / \mathrm{F})\end{array}$ & $\begin{array}{c}\text { Majoring } \\
\text { in the L3? }\end{array}$ & $\begin{array}{c}\text { Studying } \\
\text { overseas? }\end{array}$ & $\begin{array}{c}\text { L3 learning span } \\
\text { (until May, 2020) }\end{array}$ \\
\hline Tracy & Italian & 19 & F & Yes & No & Around 8 months \\
Acacia & Thai & 19 & F & Yes & No & Around 8 months \\
\hline
\end{tabular}




\subsection{Research Procedures}

Quantitative and qualitative approach are mutually complemented (Dörnyei, 2007), and thus the data of the interview designed on the basis of questionnaire answers should be comprehensive and credible. After designing the questionnaire and interview questions, the questionnaire was distributed to the interviewees. Interviews were conducted based on participants' answer in April, 2020. Due to the outbreak of corona-virus, all the interviews were conducted online for social-distancing reason.

\subsection{Data Analysis Methods}

Recordings of the interview were translated and transcribed into texts first. Then transcripts were coded iteratively in order to simplify and meanwhile highlight meaningful items in collected data (Dörnyei, 2007). Second-level coding was used to interpret data in a more effective way since it is an indispensable part to amalgamate closely related group into a broader category (Dörnyei, 2007). Moreover, when centering on the correlations of participants' answer, thematic analysis was practiced to conclude crucial characteristics and summarize unexpected ideas (Braun \& Clarke, 2006).

\section{Findings}

Two participants' L3 learning motivation are analyzed separately under the Self-discrepancy Model for Language Learners, with the presentation of excerpts of interview transcripts. A four-leaf clover illustration is presented in each case. Each leaf represents one motivation modes (Figure 1) and the strength of the motives is visualized by the size of the leaves. The data shows this model can reflect the characteristics of learning motivation of varied L3s and how Own-Ideal-driven motivation can be displayed in different angles, which highlights the complexity and dynamics of L3 motivation.

\subsection{Tracy's Italian Learning Motivation}

Own-Ideal L3 Self is the major motivator for Tracy to learn Italian, with some influences by The Own Ought-to Self (Figure 2). Thinking that learning a European language might conduce to her future development, she decided to learn Italian due to the "fascination of this language".

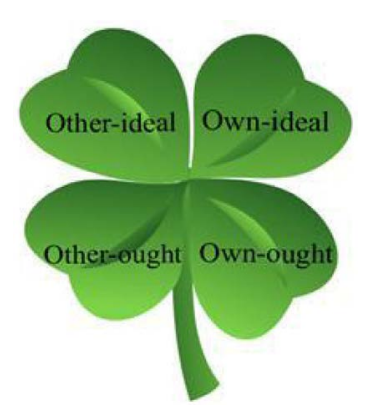

Figure 1. Four leaf clover of self-discrepancy model for language learners. 


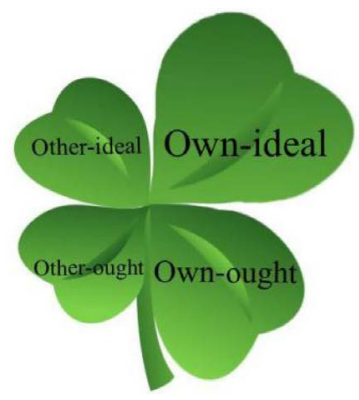

Figure 2. Tracy's self-discrepancy model.

The most salient indicator of her strong Own-Ideal L3 Self is her Ideal Multilingual Self (Henry, 2017) cultivated by her international identity which is the product from educational environment.

Excerpt 1

Don't you reckon that being a multilingual person is cool? I will respect those people.

According to Henry (2017), Ideal Multilingual Self could become a powerful factor to create additional motivation for language learning. The result of Pavlenko (2006)'s experiment also revealed that being a multilingual person makes people feel "enjoyable", which is similar with Tracy's description. The rationale behind the generation of Ideal Multilingual Self is her strong international identity. She refers directly to her favorable impression of Italian community and cosmopolitan community, thinking that Italian is a step for her to become a global citizen:

Excerpt 2

I wish to make acquaintance with native speakers of Italian because I am longing to experience local culture in Italy to appreciate the cultural differences between China and the West.

The formation of her international identity is attributed to her educational environment to a large extent, which is in alignment with the notion of L3 learning experience:

Excerpt 3

I evaluate myself have a strong sense of international identity, mainly because more often than not, my university will instill such concept to me.

Studying in the high school (Shenzhen Foreign Languages School) and the university (Shanghai International Studies University) where foreign language learning is paid due attention to, Tracy has been surrounded by polyglot peers, foreign teaching materials and foreign teachers etc. All these factors, from a macro-perspective, have contributed to her future image of being a multilingual person to integrate into the international community.

Despite such a strong Own-Ideal Self, Other-Ought-to Self has been found antithetical to Tracy's language learning motivation. It is the Own-Ought-to Self that could be deemed as the second motivator for her to learn Italian.

During her earlier education, from primary school to university, numerous 
exams have gradually whittled down her fear of examination. She clearly claims that exams will not motivate her to work harder. Moreover, other people will not put her under the pressure to study:

Excerpt 4

The only person that I need to defeat is myself.

Although Other-Ought-to Self is not obvious in this case, Tracy has indeed been influenced by some important others-her parents. It should be noticed that the important others (parents) do not contribute to the formation of her Other-ought-to self but to Own-Ought-to Self. Despite the fact that her parents did not put her under pressure, Tracy imagines that her parents actually have such expectations for their daughter to secure a successful career. This self-created obligation pushed her to move forward:

Excerpt 5

My parents have exerted no burdens on me, which makes me work harder because if I don't do well, I think they may feel sad but they won't tell me.

\subsection{Acacia's Thai Learning Motivation}

Acacia is influenced mainly by Own-Ideal Self (Figure 3). Acacia has gradually built up her interest towards Thai since high school. She learned basic Thai on her own initiative before she systematically learned it in the university (Beijing Foreign Studies University).

Because of interest, she has also been exposed to a plenty of local cultural products, for example, TV dramas, short videos, history books, interviews of Thai stars and so forth. All of them contribute to the construct of her Own-Ideal Self:

Excerpt 6

After learning (Thai) a little bit, I unexpectedly found that I could understand parts of the drama...... I need to keep learning it, so that I no longer need to wait for others' translation.

Acacia's motivation generated from cultural products can be explained by the mere exposure effect (Zajonc, 1968) in the realm of psychology. The mere exposure effect suggests that when being repeatedly exposed to a certain stimulus, individuals' affection towards it will increase. Given the omnipresence of the internet which plays an vital role in people's daily lives, learners like Acacia can

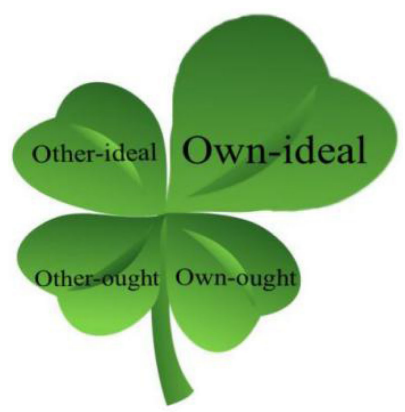

Figure 3. Acacia's self-discrepancy model. 
gain abundant academic or recreational sources of specific language. Those cultural products unconsciously exert a positive influence on Acacia's Thai learning. It is conspicuous that she has formed a future image of being an excellent Thai user.

Acacia further emphasized that she has been attracted especially by historical TV dramas which she described as "appealing". In addition, Acacia is a fan of a Thai super star called Lisa:

\section{Excerpt 7}

I want to become fluent (in Thai) and have the ability to chat with her.

By contrast, there is evidences supporting that Acacia will hardly be motivated by Other/Own Ought-to Self (such as teacher or exams):

\section{Excerpt 8}

I think teachers may not influence me a lot...... I will definitely not be motivated by exams. Only thinking about exams is terrible......

\section{Discussion}

Given the results from two participants' interview, this study finds that the four facets in Self-discrepancy Model for language learners can coexist due to the influence of learning experience. For example, Tracy is driven by Own-Ideal Self and her Own-Ought-to Self stimulated from her imaginary parents expectation. Chen (2012) has also argued that some learners have the potential to change from one self to another since the concept of Ideal self and Ought-to Self is proved to be overlapping.

As confirmed by Higgins (2014), a discrepancy will vary momentarily across different circumstances. It was also found that L3 Learning Experiences contribute to the variance of one's learning motivation and it could also shape their Ideal/Ought-to Selves to some extent. Tracy's Own-Ideal Self has been continuously influenced by her high school and university where the notion of multilingualism is promoted; Acacia's Own-Ideal Self has generally been triggered by the exposure of Thai cultural products. The significance of this finding lies in the fact that previous studies which based on L2MSS have focused mainly on examining the Ideal and Ought-to Self without giving the third component-L2 Learning Experience enough importance. Dörnyei (2019) highlighted that this facet is as crucial as another two Self-guides and there has been sufficient evidences to justify that the L2 Learning Experience is one of the most influential predictor of motivational-relevant behavior.

\section{Conclusion}

Combining two relatively under-theorized area, L3 and LOTEs, our findings suggest that L3 learning experiences can shape learners' Ideal/Ought-to Self and the four facets in Self-discrepancy Model for Language Learners (Own/Other-Ideal, Own/Other-Ought) could coexist alongside each other. Receiving education in a language-appreciating environment and influencing by foreign culture could 
shape learner's multilingual identity and interest towards a certain language. Through long-term study of L3, it is possible that the learner internalizes others' expectation or digest external pressure and maintain strong self-directed motivation. Additionally, the fact that several motivational Selves work simultaneously indicates the complexity and dynamics of L3 learning motivation.

This study also has pedagogical implications. Due to the profound impact of L3-learning environment, teachers are expected to help L3 learners understand their future usage of L3 and to create learning atmosphere in which foreign languages are highly valued. This study has several limitations. The sample size of case studies is small. Without a longitudinal motivation trajectory, L3 motivational variations across time were not reflected in this study. Therefore, further studies are encouraged to explore more in studying LOTEs as L3 in Chinese context.

\section{Conflicts of Interest}

The author declares no conflicts of interest regarding the publication of this paper.

\section{References}

Boo, Z., Dörnyei, Z., \& Ryan, S. (2015). L2 motivation Research 2005-2014: Understanding a Publication Surge and a Changing Landscape. System, 55, 145-157. https://doi.org/10.1016/j.system.2015.10.006

Braun, V., \& Clarke, V. (2006). Using Thematic Analysis in Psychology. Qualitative Research in Psychology, 3, 77-101. https://doi.org/10.1191/1478088706qp063oa

Chen, S. A. (2012). Motivation and Possible Selves: An Interview Study of Taiwanese EFL Learners. Language Education in Asia, 3, 50-59. https://doi.org/10.5746/LEiA/12/V3/I1/A05/Chen

Dörnyei, Z. (2007). Research Methods in Applied Linguistics: Quantitative, Qualitative and Mixed Methodologies. Oxford: Oxford University Press.

Dörnyei, Z. (2009). The L2 Motivation Self System. In Z. Dörnyei, \& E. Ushioda (Eds.), Motivation, Language Identity and the L2 Self (pp. 9-42). Multilingual Matters. https://doi.org/10.21832/9781847691293-003

Dörnyei, Z. (2019). Towards a Better Understanding of the L2 Learning Experience, the Cinderella of the L2 Motivational Self System. Studies in Second Language Learning and Teaching, 9, 19-30. https://doi.org/10.14746/ssllt.2019.9.1.2

Dörnyei, Z., \& Al-Hoorie, A. H. (2017). The Motivational Foundation of Learning Languages Other than Global English: Theoretical Issues and Research Directions. The Modern Language Journal, 101, 455-468. https://doi.org/10.1111/modl.12408

Dörnyei, Z., \& Ushioda, E. (2011). Teaching and Researching Motivation (2nd ed.). Routledge.

Gearing, N., \& Roger, P. (2018). Ebbs and Flows: A Longitudinal Study of an English Language Instructor's Motivation to Learn Korean. Journal of Language, Identity \& Education, 17, 292-305. https://doi.org/10.1080/15348458.2018.1465343

Henry, A. (2011). Examining the Impact of L2 English on L3 Selves: A Case Study. International Journal of Multilingualism, 8, 235-255.

https://doi.org/10.1080/14790718.2011.554983 
Henry, A. (2017). L2 Motivation and Multilingual Identities. The Modern Language Journal, 101, 548-565. https://doi.org/10.1111/modl.12412

Higgins, E. T. (1987). Self-Discrepancy: A Theory Relating Self and Affect. Psychological review, 94, 319. https://doi.org/10.1037/0033-295X.94.3.319

Higgins, E. T. (2014). Promotion and Prevention: How "0" Can Create Dual Motivational Forces. In J. W. Sherman, B. Gawronski, \& Y. Trope (Eds.), Dual-Process Theories of the Social Mind (pp. 423-435). Guilford Press.

Huang, S. C. (2019). Learning Experience Reigns-Taiwanese Learners' Motivation in Learning Eight Additional Languages as Compared to English. Journal of Multilingual and Multicultural Development, 40, 576-589.

https://doi.org/10.1080/01434632.2019.1571069

Islam, M., Lamb, M., \& Chambers, G. (2013). The L2 Motivational Self System and National Interest: A Pakistani Perspective. System, 41, 231-244. https://doi.org/10.1016/j.system.2013.01.025

Lanvers, U. (2016). Lots of Selves, Some Rebellious: Developing the Self Discrepancy Model for Language Learners. System, 60, 79-92.

https://doi.org/10.1016/j.system.2016.05.012

Pavlenko, A. (2006). Bilingual Selves. Bilingual Education and Bilingualism, 56, 1. https://doi.org/10.21832/9781853598746-003

Róg, T. (2017). Successful L3 Learning in a Study Abroad Context: A Personal Narrative. Language and Intercultural Communication, 17, 288-305. https://doi.org/10.1080/14708477.2016.1277232

Subekti, A. S. (2018). L2 Motivational Self System and L2 Achievement: A study of Indonesian EAP Learners. Indonesian Journal of Applied Linguistics, 8, 57-67. https://doi.org/10.17509/ijal.v8i1.11465

Wang, T. Y., \& Liu, Y. C. (2017). Dynamic L3 Selves: A Longitudinal Study of Five University L3 Learners' Motivational Trajectories in China. The Language Learning journal, 1-12. https://doi.org/10.1080/09571736.2017.1375549

Zajonc, R. B. (1968). Attitudinal Effects of Mere Exposure. Journal of Personality and Social Psychology, 9, 1. https://doi.org/10.1037/h0025848 